\title{
DUODENAL - ILEAL FISTULA, RARE VARIANT OF PENETRATING OF DUODENAL ULCER, ASSOCIATED WITH SIGMOID CANCER
}

\author{
O. Vaida ${ }^{1 凶}$, M.Gh. Pandrea ${ }^{1}$, G.M. Bejenaru ${ }^{2}$, A. Andercou ${ }^{3}$ \\ 1) Department of General Surgery, Municipal Hospital Dej, Romania \\ 2) Department of Anesthesia and Intensive, Municipal Hospital Dej, Romania \\ 3) University of Medicine and Pharmacy „Iuliu Hațieganu”, \\ II ${ }^{\text {nd }}$ Surgical Unit, Cluj-Napoca, Romania
}

\begin{abstract}
DUODENAL - ILEAL FISTULA, RARE VARIANT OF PENETRATING OF DUODENAL ULCER, ASSOCIATED WITH SIGMOID CANCER (Abstract): Duodeno-ileal fistula has benign (penetration of the duodenal ulcer) or malignant etiology. We present the case of a 73 years old woman, with history of right colectomy; she was admitted in our surgical unit for abdominal pain, fecaloid vomiting, fetid halitosis, bloody diarrhea, weight loss and impaired general condition. A moderate anemia and several electrolytic disorders have been revealed by the laboratory exams. The upper digestive endoscopy revealed a penetrating duodenal ulcer with duodeno-ileal fistula and colonoscopy a stenosant tumor at $25 \mathrm{~cm}$ of the anal edge. After the correction of anemia and electrolytic disorders an exploratory laparotomy was performed The exploration noted a tumor mass which included duodenum and gastric antrum, gallbladder, ileum, sigmoid loop and the great omentum. The careful dissection confirmed the sigmoid cancer invading the antropyloric region and the double duodenal ulcer with pancreatic penetration and duodeno-ileal fistula. Multiple organs resection were performed: anterograde cholecystectomy; segmental enterectomy; $3 / 4$ distal gastric resection with precolic gastro-jejunal anastomosis (Leger type); sigmoid resection with end-to-end colo-colic anastomosis. The postoperative course was uneventful. Several data from the literature were discussed. CONCLUSIONS: Duodeno-ileal fistula is an accidental variety of ulcer penetration caused by particular morphopathological conditions. Surgical treatment of gastro-digestive fistulas should be applied early with a correct balancing of the patient. Operation is complex and often atypical and implies multiple organs resections. In this particular case, the sigmoid cancer which invaded the distal part of the stomach complicated much more the surgical procedure.
\end{abstract}

KEY WORDS: DUODENAL ULCER; PENETRATION; DUODENAL-ILEAL FISTULA; METACHRONOUS COLIC CANCER; SIGMOID RESECTION; DISTAL GASTRECTOMY; GASTROJEJUNOSTOMY

SHORT TITLE: Duodenal-ileal fistula \& sigmoid cancer

HOW TO CITE: Vaida O, Pandrea MG, Bejenaru GM, Andercou A. [Duodenal - ileal fistula, rare variant of penetrating of duodenal ulcer, associated with sigmoid cancer]. Jurnalul de chirurgie (Iaşi). 2013; 9(3): 257-260. DOI: 10.7438/15849341-9-3-9.

\section{INTRODUCTION}

Penetration, complication of ulcer disease determine sometimes, adherence to a hollow organ. Through the inflammatory process and clorhidro-peptic aggression, can occur internal fistulas [1]. Between them gastro-jejuno-colic fistula is classically noted [2-7]. Duodeno-ileal fistula is rarely reported.

\section{CASE REPORT}

A 73 years old woman was admitted to Municipal Hospital Dej, with abdominal pain, fecaloid vomiting, fetid halitosis, 
bloody diarrhea, weight loss and impaired general condition. From she's medical history we retained a right colic flexure neoplasm, 34 years ago, for which right hemicolectomy has been performed. Physical exam revealed a cachexia, an anxious facies with the palpebral edemas, pallor, hypotonic muscles and pretibial edema. The abdominal palpation revealed 10 $\mathrm{x} 10 \mathrm{~cm}$ painful mass, located in the superior right quadrant.

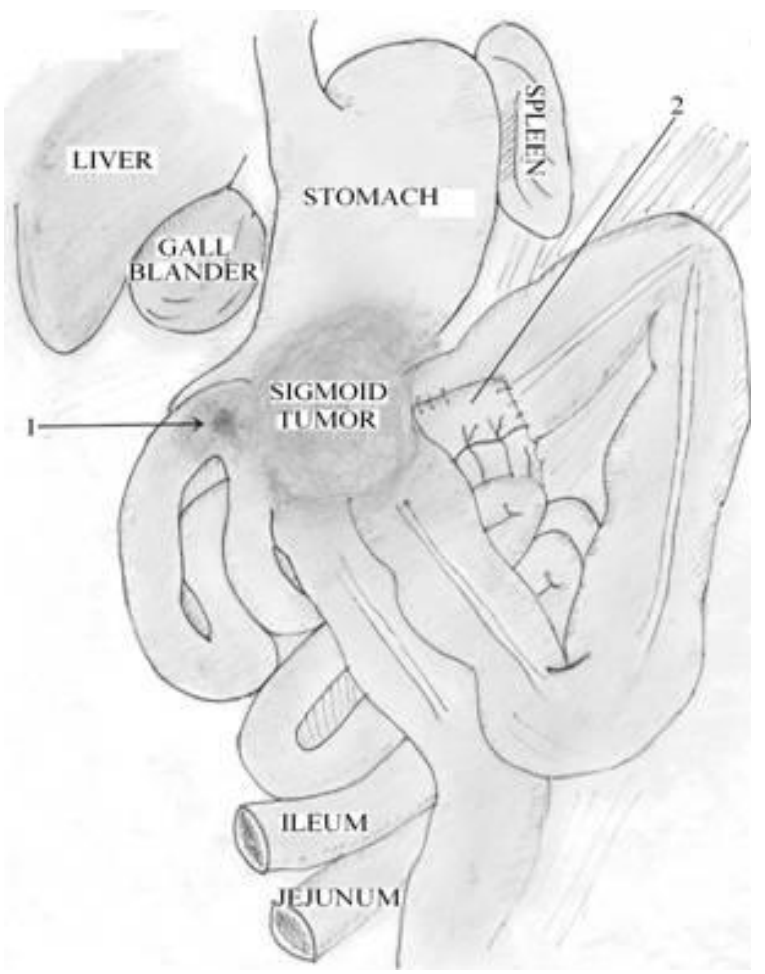

Fig. 1 Duodenal-ileal fistula and associated sigmoid tumor invading the gastric antrum

1 penetrating duodenal ulcer with duodenal-ileal fistula; 2 ileo-transverse anastomosis after right colectomy

Abdominal ultrasound noted a colic thickness. The upper digestive endoscopy noted feaces into the stomach and two duodenal ulcers and raise the suspicion of duodeno-colic fistula. Colonoscopy revealed a hemorrhagic and stenosant tumor at $25 \mathrm{~cm}$ of the anal edge. Laboratory tests have shown elevated ESR (Erythrocytes Sedimentation Rate $)(81 \mathrm{~mm} / 1 \mathrm{~h} ; 123$ $\mathrm{mm} / 2 \mathrm{~h}$ ), leucocytosis (WBC $12.20 \mathrm{~K} / \mu \mathrm{L}$ ), moderate anemia (RBC $3.54 \mathrm{M} / \mu \mathrm{L}$, Haemoglobin ( $\mathrm{Hb})$ 9.6g/dL, Hematocrit
(Ht) $28.8 \%$ ) and a hypoproteinemia (Total Proteins $5.2 \mathrm{~g} / \mathrm{dL}$ ) and several electrolytic disorders $\left(\mathrm{Na}^{+} 142 \mathrm{mmol} / \mathrm{L} ; \mathrm{K}^{+} 3.9 \mathrm{mmol} / \mathrm{L}\right.$; $\left.\mathrm{Ca}^{++} 8.37 \mathrm{mg} / \mathrm{dL} ; \mathrm{Mg}^{++} 1.91 \mathrm{mg} / \mathrm{dL}\right)$. The CT scan and tumor markers were not performed for technical reasons.

After correction of anemia and serum electrolytes an exploratory laparotomy was performed. An iterative median laparotomy (right colectomy several years ago) was done. The exploration noted a tumor mass which included duodenum and gastric antrum, gallbladder, ileum, sigmoid loop and the great omentum. The careful dissection confirmed the sigmoid cancer invading the antropyloric region and double duodenal ulcer with pancreatic penetration and duodeno-ileal fistula (Fig. 1). We performed several resections in the following order: anterograde cholecystectomy; segmental enterectomy (upstream and downstream of the duodeno-ileal fistula); $3 / 4$ distal gastric resection with precolic gastro-jejunal anastomosis (Leger type); sigmoid resection with end-to-end colo-colic anastomosis (Fig. 2).

Postoperative treatment included blood transfusions, hydro-electrolyte and-acid base corrections, antibiotics, preventive antithrombotic treatment and proton pump inhibitors therapy.

The postoperative follow up was uneventful with intestinal transit recovery after 72 hours. The patient was discharged in $11^{\text {th }}$ postoperative day.

The histopathological exam revealed a colic adenocarcinoma with gastric invasion, $\mathrm{pT}_{4} \mathrm{~N}_{0} \mathrm{M}_{0} \mathrm{G}_{2}$. No venous, lymphatic emboli were noted neither perineural invasion. 12 lymph nodes were found and dissected on sigmoid resection specimen and no lymph nodes metastases were found.

\section{DISCUSSION}

In the case presented are associated two diseases with rare but explainable evolution: a sigmoid cancer with invasion of gastric antrum and a double ulcer complicated by posterior pancreatic penetration and duodeno-ileal fistula. A 
penetrating duodenal ulcer as depicted is rare in nowadays because of efficacy of protons pumps inhibitors therapy; however the ulcer penetration remains a serious complication associated with operative difficulties and postoperative morbidity $[3,8$ 10]. The duodenal-ileal fistula as ulcer complication, is also rare [11], and is explained in presented case, by the new anatomic conditions following right colectomy.

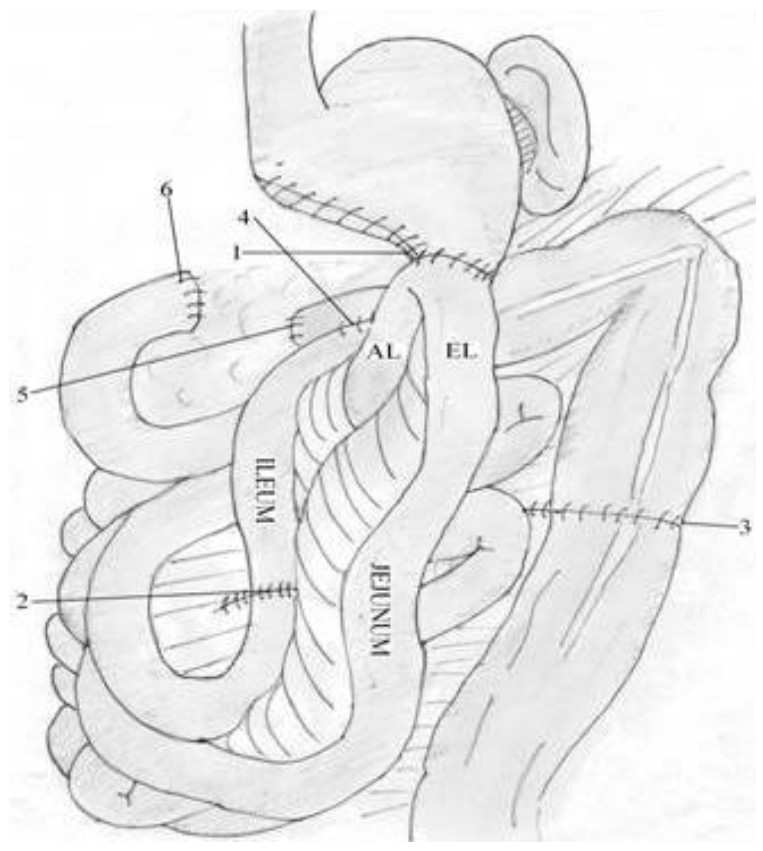

Fig. 2 Reconstruction of digestive tract after multiple organs resections

1 Precolic gastrojejunostomy (Leger type); 2 enteroenteral anastomosis after segmental resection of ileum; 3 colo-colic anastomosis after sigmoid resection; 4 ileo-transverse anastomosis after right hemicolectomy; 5 transverse colon stump after right hemicolectomy; 6 duodenal stump; AL afferent loop; EL efferent loop

The metachronous sigmoid cancer after a right colon cancer is a well known issue [12,13]. In presented case, a lack of colonoscopic and oncologic follow-up due to the very long timing of recurrence (34 years) explains the tumor stage at the presentation. In the same time, we speculate the inflammatory mass following duodenal ulcer penetration was the trigger factor for the sigmoid loop to "isolate" the inflammation and the colic cancer gastric invasion was then secondary.
The exploratory laparotomy allowed the lesion inventory and correct diagnosis. The surgery procedure was challenged and imposed multiple visceral resections. The choice of digestive type reconstruction was logical in the context of lesions. We performed a gastro-jejunal anastomosis fashioned in precolic manner because the transverse mesocolic retraction [12]. We have preferred a gastro-jejunal end-to-side anastomosis instead of "Roux" gastrojejunal anastomosis to short and simplify the procedure. The sigmoid resection was performed in usual manner but we preserved the superior left vessels to ensure a good vascular supply for the colon, given the antecedent of right colectomy. Despite the multiple organs resection, the postoperative course was uneventful.

The long term prognosis remains uncertain, given the disease stage and limited oncologic colic resection. Adjuvant chemotherapy is indicated but was refused by the patient. A colonoscopic control was provided one year after the procedure.

\section{CONCLUSION}

Duodeno-ileal fistula is an accidental variety of ulcer penetration caused by particular morphopathological conditions. Surgical treatment of gastro-digestive fistulas should be applied early with a correct balancing of the patient. Operation is complex and often atypical and implies multiple organs resections. In this particular case, the sigmoid cancer which invaded the distal part of the stomach complicated much more the surgical procedure. We were totally satisfied by the Leger type precolic gastrojejunostomy.

\section{CONFLICT OF INTERESTS}

None to declare.

\section{REFERENCES}

1. Gheorghescu B. Ulcerul gastric şi ulcerul duodenal In: Păun $\mathrm{R}$, editor, Tratat de medicină internă, bolile aparatului digestiv, partea I; Bucureşti: Editura Medicală; 1984. p. 225-226. 
2. Popescu I, Iacob S, Iacob R. Ulcerul gastric şi duodenal In: Popescu I, editor, Tratat de chirurgie, Vol. VIII, Partea IB, Chirurgie Generală; Bucureşti: Editura Academiei Române; 2008. p. 1326-1327.

3. Al Hajjar N, Szasz A, Miftode S, Iancu C, Bala O, Puia C. Gastrojejunocolic fistula - a rare complication of stomach surgery. 2007; 102(6); 735-737.

4. Constantinescu C. Boala ulceroasă In: Proca E, editor, Tratat de patologie chirurgicală Vol. VI; Bucuresşti: Editura Medicală; 1986. p. 9091.

5. Radu C, Pătraşcu Tr. Ulcerul duodenal In: Angelescu N, editor, Tratat de patologie chirurgicală - Vol. I; Bucureşti: Editura Medicală; 2002. p. 1511-1512.

6. Nana A. Fistulele gastrice interne In: Burghele Th, editor, Patologie chirurgicală - Vol. V; Bucureşti: Editura medical; 1974. p. 152-155.

7. Pascu O. Ulcerul gastric şi duodenal In: Pascu $\mathrm{O}$, editor, Tratat de gastroenterologie clinică Vol. I; Bucureşti: Editura Tehnică; 1996. p. 323-325.

8. Kurbonov KM, Ibodov ST. Diagnosis and surgical treatment of penetrating duodenal ulcer. Khirurgiia. 2001; (2): 9-11.
9. Fujihara S, Mori H, Nishiyama N, Kobara H, Masaki T. Giant gastric ulcer penetrating into the pancreas. Arab J Gastroenterol. 2012; 13(3): 158-160.

10. Vashist YK, Yekebas EF, Gebauer F, et al. Management of the difficult duodenal stump in penetrating duodenal ulcer disease: a comparative analysis of duodenojejunostomy with "classical" stump closure (Nissen-Bsteh). Langenbecks Arch Surg. 2012; 397(8): 12431249.

11. Altorjay I. Surgical treatment of inantition due to jejunal peptic ulcer and duodeno-ileal fistula. Pathol Biol. 1961; 102: 2528-2530.

12. Dragomir C, Scripcaru V, Dajbog, E Cancerul de colon - In: Popescu I, editor, Tratat de chirurgie, Vol. IX; Bucureşti: Editura Academiei Române; 2009. p. 226-2263.

13. Cone MM, Beck DE, Hicks TE, et al. Timing of colonoscopy after resection for colorectal cancer: are we looking too soon? Dis Colon Rectum. 2013; 56(11): 1233-1236.

14. Leger L. Gastrectomie avec anastomose gastro-jejunale par le travers de anse - Notes de technique chirurgicale. Press Medicale Paris. 1950; 58(58): 999. 